\title{
A simple solution enabling quantitative sampling of freshwater and marine sediments covered by dense submerged vegetation
}

\author{
Ryszard Kornijów • Timo Kairesalo
}

Received: 14 February 2013/Revised: 5 April 2013/Accepted: 4 May 2013/Published online: 15 June 2013

(C) The Author(s) 2013. This article is published with open access at Springerlink.com

\begin{abstract}
The biological and physico-chemical structure of near bottom habitats located under densely growing submerged vegetation, and their significance in the functioning of whole aquatic ecosystems, are very little known due to difficulties in sampling. Corertype samplers, believed to be the best in littoral studies, do not work properly in such places, because their tube opening is easily clogged by plant shoots, acting as a stopper. In order to overcome this problem, an alteration to the shape of the tube ending is proposed. This can be done by its trimming at an accurate angle, or by fitting (permanently or interchangeably) a metal collar made of stainless steel to its end, so that the ending would resemble the shape of a needle. The modification can be applied to virtually all corer samplers. It was found to be efficient while sampling sediment cores for the purposes of both hydrobiological and paleolimnological studies on heavily overgrown macrophyte-dominated water ecosystems.
\end{abstract}

Handling editor: Jasmine Saros

R. Kornijów $(\square)$

Department of Fisheries Oceanography and Marine

Ecology, National Marine Fisheries Research Institute,

Kołłątaja 1, 81-332 Gdynia, Poland

e-mail: ryszard.kornijow@mir.gdynia.pl

T. Kairesalo

Department of Ecological and Environmental Sciences, University of Helsinki, Niemenkatu 73,

15140 Lahti, Finland
Keywords Corer-type samplers · Sediments . Submerged vegetation

\section{Introduction}

Sediment sampling methods have undergone a long evolution (Elliott \& Tullett, 1978; Downing, 1984; IAEA, 2003). In the past, box-type samplers were used for both sediment sampling and sectioning. Currently, corer-type samplers, including both open-barrel and gravity corers, are believed to be the most suitable. They are particularly useful for sampling in the littoral zone, where various hard objects, like stones, sticks, or shoots and roots of aquatic vegetation occur. Moreover, they permit the collection of so-called undisturbed sediment cores (Blomqvist, 1991; Wright, 1991; Glew et al., 2001; Schumacher, 2005).

The diameter of a tube sampler should be large enough to provide sufficient material for analysis, minimize the possibility of sediment compression, and avoid the impact of smearing along the core edge. An internal tube diameter of $4-12 \mathrm{~cm}$ is considered optimal for most hydrobiological and paleolimnological investigations (Downing, 1984; IAEA, 2003). However, in situations where the bottom of a water ecosystem is covered with a dense carpet of submerged vegetation, sampling by means of such a core sampler becomes problematic or even impossible. The plant material clogs the tube opening, acting as a stopper. This does not allow the penetration of 
sediment into the tube. In such a case, the sample collected contains turbid water instead of the actual sediment material. This particularly concerns bottoms overgrown with thick beds of creeping charales or mosses, and to a lesser extent those covered by protruding plants such as pondweeds Potamogeton spp. or water milfoils Myriophyllum spp. In such a situation, the researcher usually attempts sampling sediments in other places. This might finally be successful, but in places without or with sparse vegetation. The material obtained this way is not representative of either weedy or open water habitats.

A solution might be the application of a tube of a very small diameter. This, however, has negative consequences, for example the necessity to collect a high number of samples to obtain sufficient quantity of material. In the case of paleolimnological studies, additional disadvantages of this approach are the compression of sediment and smearing (Glew et al., 2001; IAEA, 2003). Therefore, a core obtained this way does not meet the criteria of an intact core.

The issue is very rarely addressed in the literature (Stoner et al., 1983), and no effective solution has been developed so far permitting the collection of samples of bottom sediments in habitats heavily overgrown by submerged vegetation. In consequence, the chemical and physical properties of the sediments, as well as benthic biotic communities in such habitats are very little known.

This paper presents a simple proposal that may permit overcoming the problem of clogging of tube samplers with macrophytic shoots. It involves changing the shape of the sampler tube ending. It has been successfully applied in both hydrobiological and paleolimnological studies on heavily overgrown macrophyte-dominated lowland lakes, with submerged plant biomass during summer varying from about 3 to $5 \mathrm{~kg}$ wet weight $\mathrm{m}^{-2}$ (e.g., Tarkowska-Kukuryk \& Kornijów, 2008; Kornijów et al., 2013; Kowalewski et al., 2013).

\section{Description of the improvement}

Restricted access to the sediment due to the presence of densely growing vegetation can be overcome by modifying the shape of the ending of the sampler tube in a way that it resembles a needle. Owing to this solution, penetration through macrophyte carpets progresses smoothly. This permits taking quantitative samples of sediments, and even intact cores of any length.
Changing the shape of the tube ending can be obtained by its trimming at an angle of about $30^{\circ}$, or by fitting (permanently or interchangeably) a metal collar made of stainless steel at the end of the tube (Fig. 1A). The advantage of the latter solution is that the sharp metal edges facilitate the penetration by the apparatus in hard sediment. They also easily intersect plant shoots, if they stop on the edge of the tube. The internal diameter of the metal collar should be the same as the internal diameter of the corer tube, but the external one can be larger by about $2 \mathrm{~mm}$. The external diameter of the collar slightly larger than that of the tube, like the oblique cutting edge, additionally decreases friction forces on the outer tube wall when it is driven, and increases the ability of the device to penetrate with greater efficiency.

While using the metal collar, the possibility of chemical contamination of the sediment collected with metals contained in the collar should be considered. This is particularly important should the sediments be analyzed for heavy metals. In such a case, it is safer to alter the shape of the acrylic tube ending by its trimming at an accurate angle.

The modification described can be used in virtually any coring equipment. In its simplest and easiest-to-use version, it can be an open-barrel corer-a tube of up to approximately $2 \mathrm{~m}$ in length, and open at both the top and bottom, driven vertically into the sediment (Fig. 1B). At the end of the drive, the top of the tube is closed, and the tube together with the sediment is retrieved. This kind of device is very easy to operate, and is sufficient for effective sampling of sediments in many shallow habitats. The asymmetric ending of the tube can also be applied in more sophisticated gravity corers, like Kajak or UWITEC corers, to sample at greater depths (Fig. 1B).

After collecting a sample, it is possible to take a water sample (using a vacuum pump) from above the sediment for chemical analysis, or to measure the water properties in situ by means of appropriate probes inserted to the tube, if it can be detached from the head sampler (Fig. 1C). The sediment core can be analyzed as a whole or sectioned at a given resolution using special devices for slicing (e.g., Wright, 1991; Winterhalter, 2001; Kornijów, 2013).

Concluding remarks

An advantage of a needle-shaped asymmetrical cutting edge, applied in our solution, is that it can 
Fig. 1 The needle-shaped ending of a tube, with a metal collar at the bottom (A) left applied to a simple open-barrel corer, right- - to UWITEC gravity corer (B) after disconnection from the sampler head, with an extruder inside and sediments ready for nearbottom water measurements or sediment sectioning $(\mathbf{C})$
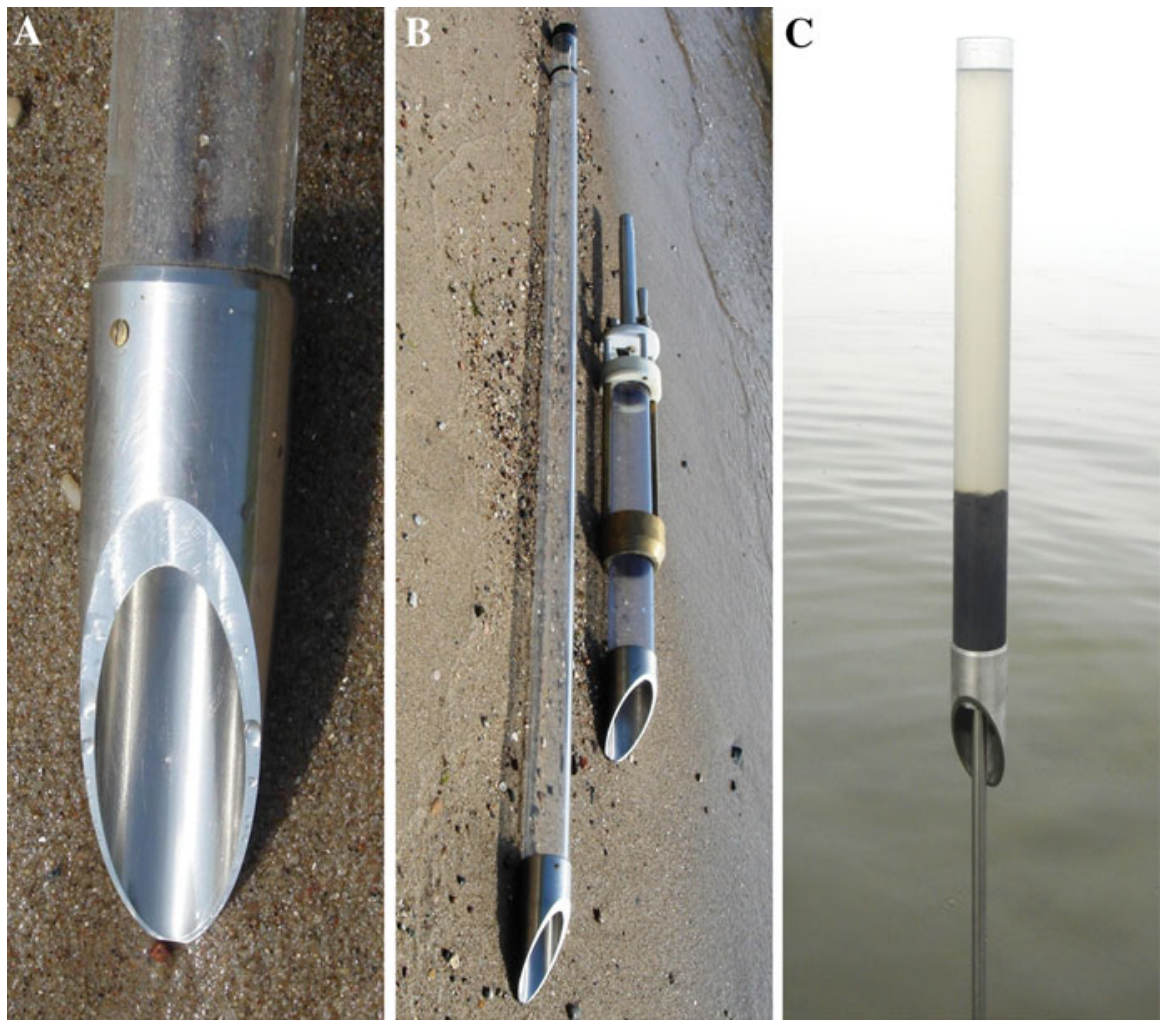

concentrate the cutting force to a small part of the advancing cutting edge. This decreases the initial resistance of penetration.

The asymmetry of the cutting edge, however, may raise certain doubts concerning the dynamics of sediment collection. As a result of the uneven distribution of the corer mass, the sampler might have a tendency for tipping over when it begins penetrating the sediment. This is not the case here, however, due to the frequently occurring softness of highly hydrated surface sediment, and the considerable weight of a sampler lowered on a rope. In places with more compact sediments the problem may be overcome by pushing the sampler by hand into the sediment using a drive rod, connected to the top of the core tube.

Another potential problem is related to uneven entering the sediment by an asymmetrical tube edge. The surface sediment is unsupported on the side of the sample opposite the cutting edge. Under these conditions, the surface material may be deflected away from the core tube, and not be incorporated into the sample (the issue discussed in details, e.g., by Glew et al., 2001, p. 82, Fig. 5). In our opinion, such forces should not be produced if the oblique core ending is applied to open-barrel corers. They may be expected in the case of some gravity corers where the water flow may be disrupted by the flow-actuated seal. Therefore, we recommend that the initial phase of driving a tube into the sediment be proceeded very gently.

Acknowledgments The work was partly supported by the State Committee for Scientific Research, Project No. P06S00127. Our thanks are due to Małgorzata Kornijów for the linguistic verification of the paper, and to Leszek Błędzki for valuable comments on the manuscript.

Open Access This article is distributed under the terms of the Creative Commons Attribution License which permits any use, distribution, and reproduction in any medium, provided the original author(s) and the source are credited.

\section{References}

Blomqvist, S., 1991. Quantitative sampling of soft-bottom sediments. Problems and solutions. Marine Ecology Progress Series 72: 295-304.

Downing, J. A., 1984. Sampling the benthos of standing waters. In Downing, J. A. \& F. H. Rigler (eds), A Manual on Methods for the Assessment of Secondary Productivity in Fresh Waters. Blackwell Scientific Publications, Oxford: 87-130. 
Elliott, J. M. \& P. A. Tullett, 1978. A Supplement to a Bibliography of Samplers for Benthic Invertebrates. Freshwater Biological Association, Occasional Publication No. 20, Ambleside.

Glew, J. R., J. P. Smol \& W. M. Last, 2001. Sediment core collection and extrusion. In Last, W. M. \& J. P. Smol (eds), Tracking Environmental Change Using Lake Sediments, Vol. 1., Basin analysis, coring, and chronological techniques. Kluwer Academic Publishers, Dordrecht: 73-105.

IAEA, 2003. Collection and Preparation of Bottom Sediment Samples for Analysis of Radionuclides and Trace Elements. IAEA-TECDOC-1360. IAEA, Vienna [available on internet at http://www-pub.iaea.org/MTCD/publications/ PDF/te_1360_web.pdf]. Accessed 13 May 2013.

Kornijów, R., 2013. A new sediment slicer for rapid sectioning of the uppermost sediment cores from marine and freshwater habitats. Journal of Paleolimnology 49: 301-304. doi:10.1007/s10933-012-9655-9.

Kornijów, R., G. A. Kowalewski., S. McGowan., A. Kaczorowska, M. Gąsiorowski., M. Wasiłowska., M. Obremska. \& M. Suchora, 2013. Over 200 years intensive drainage practices induce ecosystem state change in a shallow lake from Poland. Ecosystems (submitted).

Kowalewski, G. A., R. Kornijów., S. McGowan., M. Suchora., K. Bałaga., A. Kaczorowska., M. Gąsiorowski., A.
Wasiłowska. \& T. Namiotko, 2013. Disentangling natural and anthropogenic drivers of changes in a shallow, macrophyte dominated lake Rotcze (Eastern Poland). Aquatic Botany 106: 1-13.

Schumacher, B., 2005. Collection of Undisturbed Surface Sediments: Sampler Design and Initial Evaluation Testing. U.S. Environmental Protection Agency Office of Research and Development, Washington, DC [available on internet at http://www.epa.gov/esd/cmb/pdf/USS_Sampler_FINAL_ REPORT.pdf]. Accessed 13 May 2013.

Stoner, A. W., H. S. Greening, J. D. Ryan \& R. J. Livingston, 1983. Comparison of macrobenthos collected with cores and suction sampler in vegetated and unvegetated marine habitats. Estuaries 6: 76-82.

Tarkowska-Kukuryk, M. \& R. Kornijów, 2008. Influence of spatial distribution of submerged macrophytes on Chironomidae assemblages in shallow lakes. Polish Journal of Ecology 56: 747-758.

Winterhalter, B., 2001. GEMAX - The Ultimate Corer for Soft Sediments. Oy Kart Ab, Helsinki [available on internet at www.kolumbus.fi/boris.winterhalter/GEMAX.pdf]. Accessed 13 May 2013.

Wright, H. E. Jr., 1991. Coring tips. Journal of Paleolimnology 6: $37-49$. 